\title{
Peran Fasilitas Pelayanan Kesehatan dalam Menghadapi Tantangan Rabies di Indonesia
}

\section{The Role of Health Services Facilities Against Rabies' Challenge in Indonesia}

\author{
Risqa Novita ${ }^{1}$ \\ 1) Pusat Penelitian dan Pengembangan Biomedis dan Teknologi Dasar Kesehatan, Jalan Percetakan Negara No. 23 Jakarta \\ 10560, Indonesia \\ Korespondensi: risqa@litbang.depkes.go.id
}

Submitted: 3 Juni 2019, Revised: 19 Agustus 2019, Accepted: 22 Agustus 2019

https://doi.org/10.22435/jpppk.v3i2.2005

\begin{abstract}
Abstrak
Rabies di Indonesia telah berada sejak abad 18, namun hingga saat ini Indonesia belum bebas dari rabies. Hanya 8 provinsi di Indonesia yang bebas dari rabies yaitu DKI Jakarta, Jawa Tengah, Jawa Timur, Daerah Istimewa Yogyakarta, Bangka Belitung, Kepulauan Riau, Papua, dan Papua Barat, padahal Indonesia ditargetkan bebas rabies pada tahun 2030. Rabies tidak dapat diobati karena disebabkan oleh virus Lyssa, hanya dapat dicegah melalui pendekatan One Health yaitu kesehatan manusia, kesehatan hewan, satwa liar dan kesehatan lingkungan. Upaya pencegahan itu adalah dengan pemberian vaksinasi rabies ke Hewan Pembawa Rabies (HPR) dan pemberian Post Exposure Prophylaxys (PEP) pada manusia yang tergigit oleh HPR. Pemberian PEP hanya dapat dilakukan di Rabies center atau fasilitas pelayanan kesehatan primer yang ditunjuk oleh pemerintah. Tulisan ini bertujuan untuk mengetahui peranan fasilitas pelayanan kesehatan untuk mengendalikan rabies yang sudah tersebar di 26 provinsi. Metode berupa review literatur yang dicari menggunakan kata kunci Pelayanan Kesehatan Primer, Post Exposure Prophylaxis dan Rabies di Indonesia. Hasil yang didapatkan adalah peran fasilitas pelayanan kesehatan dalam mengendalikan rabies pada manusia sangat penting, dalam hal tatalaksana pertama kali terhadap korban penyediaan Vaksin Anti Rabies (VAR) dan promosi kesehatan. Rabies dapat dicegah dengan perilaku hidup sehat, sehingga peran fasilitas pelayanan kesehatan yang ditunjuk sebagai Rabies center dapat mengoptimalkan promosi kesehatan melalui pemberian leaflet, edukasi rabies di sekolah-sekolah dasar, pemasangan spanduk rabies dan pemutaran video rabies di puskesmas atau rumah sakit di ruang tunggu pasien sehingga pasien dapat melihat dan mengetahui mengenai rabies dan pencegahannya.
\end{abstract}

Kata kunci: pelayanan kesehatan, post exposure prophylaxis, dan rabies center

\begin{abstract}
Rabies has been in Indonesia since the 18th century, but until now Indonesia has not been free from rabies yet. Only 8 provinces in Indonesia are free from rabies, namely DKI Jakarta, Central of Java, East of Java, Jogyakarta, Bangka Belitung, The Riau Islands, Papua, and West Papua. Rabies could not be treated because it caused by the virus (named Lyssavirus), which only prevented by the approach of one health in human health, animal health and wildlife animals, and environmental health. Lyssa could be prevented by a rabies vaccine program to rabid animals and post-exposure prophylaxis (PPE) in humans who bitten by rabid animals. The provision of the PPE can only be done in Rabies center or primary health service facilities designated by the government. This writing aims to know the role of health service facilities in primary or public health centers to tackle rabies which has been spread in 26 provinces. A method of review literature that sought to use the keywords was Health services in primary, Post-exposure prophylaxis, and Rabies in Indonesia. Results were the role of health service facilities in the control of rabies in humans is very important, in terms of managing the provision of VAR and the promotion of health service. Rabies can be prevented with healthy patterns of living so that the role of health service facilities which was appointed for rabies center can optimize the promotion
\end{abstract}


of health through the provision of leaflets, education in primary schools, setting banners rabies and screening of rabies in video health center or hospital patients in the waiting room so that the patient can see and know what rabies and it prevents.

Keywords: health services, post-exposure prophylaxis, and rabies center

\section{Pendahuluan}

Rabies adalah penyakit menular dari hewan ke manusia yang disebabkan oleh virus, yaitu lyssa virus dan menyebabkan tingkat kematian yang tinggi pada manusia. Menurut World Health Organization (WHO), angka kematian akibat rabies di dunia sebesar 59.000 orang setiap tahun, dan sebanyak $60 \%$ nya berasal dari Asia. Hal ini berarti setiap 20 menit ada kematian akibat rabies, dan mayoritas adalah anak-anak. ${ }^{1}$ Negara-negara di Asia yang merupakan endemis rabies adalah India, Bangladesh, Pakistan, Kamboja, Butan, Thailand, Cina, dan Indonesia. ${ }^{2,3}$

Rabies pertama kali dilaporkan di Indonesia pada tahun 1884, namun hingga saat ini Indonesia masih belum bebas dari rabies. Data yang berasal dari Subdit Zoonosis, Direktorat P2P, Kementerian Kesehatan RI, hanya 8 provinsi dari 34 provinsi di Indonesia yang bebas dari rabies, yaitu Kepulauan Riau, Bangka Belitung, DKI Jakarta, DIY, Jateng, Jatim, Papua dan Papua Barat. Provinsi Nusa Tenggara Barat semula bebas dari rabies, namun awal tahun 2019, hingga bulan Februari 2019 terdapat kematian manusia akibat rabies, yang disebut sebagai lyssa sebesar 14 orang. ${ }^{4,5}$

Tingginya kasus kematian akibat rabies (Lyssa) disebabkan antara lain penderita gigitan anjing tidak langsung menuju fasilitas pelayanan kesehatan terdekat, tingkat pengetahuan dan kepedulian masyarakat terhadap rabies dan tindakan awal yang harus dilakukan paska gigitan rabies masih rendah. Selain itu kurangnya koordinasi antara pemerintah pusat dengan daerah juga memicu lambatnya pengendalian rabies di Indonesia. Kasus rabies umumnya lebih banyak terjadi di daerah pedesaan daripada perkotaan. Mengingat rabies tidak dapat disembuhkan hanya dapat dicegah, maka pemberian Post Exposure Prophylaxis (PEP) paska gigitan sangat penting, berupa Vaksin Anti Rabies (VAR) dan Imunoglobulin Rabies (RIG) atau Serum Anti Rabies (SAR) yang diberikan ke penderita Gigitan Hewan Penular Rabies (GHPR). Ketersediaan VAR di fasilitas pelayanan kesehatan primer sangatlah penting, sebagai upaya untuk menghambat jalannya virus ke otak. Hal ini dikarenakan virus lyssa bergerak di saraf tepi manusia dan langsung menuju ke otak manusia sebagai target, dengan kecepatan perjalanan selama 12-24 mm/hari, sehingga semakin jauh dari kepala maka masa inkubasi akan semakin panjang, hingga 1 tahun. ${ }^{6}$

Upaya pengendalian rabies membutuhkan biaya yang sangat tinggi, sebagai contoh kasus pengendalian rabies di Bali tahun 2008-2009, terdapat 130 orang penderita GHPR dan tidak mendapatkan upaya pencegahan dengan pemberian PEP. Padahal PEP sudah diberikan ke lebih dari 130.000 orang penderita GHPR, namun tidak termasuk ke 130 orang tersebut. dan telah menelan biaya sebesar lebih dari US $\$ 17,4,7$

Menurut WHO, semua penderita GHPR wajib diberikan VAR. Vaksin Anti Rabies diberikan di fasilitas kesehatan layanan primer yang dapat bertindak sebagai rabies center di daerah endemis rabies. Vaksin Anti Rabies merupakan vaksin aktif yang harus diperhatikan rantai dinginnya mulai dari tingkat provinsi hingga ke daerah agar kandungan virus yang terdapat di dalamnya dapat membentuk respon antibodi optimal saat disuntikkan di tubuh penderita GHPR. ${ }^{8,9}$

Mengingat sebagian besar wilayah Indonesia, yaitu 26 provinsi belum bebas rabies, maka dibutuhkan fasilitas pelayanan kesehatan primer yang kuat sebagai ujung tombak awal untuk pengendalian rabies. Terlebih lagi kasus rabies banyak terjadi di daerah pedesaan daripada di perkotaan sehingga fasilitas kesehatan layanan primer dituntut untuk memiliki fasilitas PEP dan tenaga medis yang terlatih dalam menangani kasus rabies.

Tulisan ini adalah review literatur yang bertujuan untuk mengetahui peranan fasilitas pelayanan kesehatan primer atau puskesmas untuk melayani penderita gigitan hewan rabies dalam rangka mengendalikan rabies yang sudah tersebar di 26 provinsi. Kesiapan itu antara lain apakah VAR 
sudah tersedia optimal dan sesuai dengan rantai dingin pendistribusian vaksin. Ketersediaan VAR sangat penting sebagai upaya menurunkan angka kematian akibat lyssa.

\section{Metode}

Metode literatur review dimulai dari penelusuran kepustakaan dilakukan melalui internet dengan peramban Google, PubMed dan Elsevier. Penelusuran menggunakan kata kunci Pelayanan Kesehatan, PEP dan Rabies center.

Kepustakaan diambil dari unduhan jurnal gratis dan laman situs kesehatan internasional seperti World Health Organization (WHO) dan Office de Internationale des Epizootica/OIE atau Organisasi Kesehatan Hewan. Artikel yang digunakan sebagai rujukan sesuai dengan kriteria inklusi dan eksklusi, sebagaimana berikut ini :

- Kriteria inklusi rujukan adalah semua artikel yang berasal dari: 1) artikel penelitian, seperti penelitian case report dan penelitian surveilans serta 2) artikel review, yang menjawab pertanyaan penelitian yaitu bagaimana peranan fasilitas layanan primer dalam menghadapi tantangan rabies di Indonesia. Artikel review tersebut berasal dari penelitian kuantitatif dan kualitatif, dan artikel terbit di bawah 10 tahun terakhir.

- Kriteria eksklusi adalah artikel yang tidak sesuai dengan pertanyaan penelitian, dan artikel yang terbit di atas 10 tahun terakhir, baik berbahasa Indonesia dan Inggris.

Setelah melalui penelusuran melalui sistematika di atas, terpilih referensi yang diambil sebagai acuan penulisan ini yang mencakup 25 artikel ilmiah yang berasal dari hasil penelitian dan review artikel, seperti terlihat di dalam Gambar 1.

Hasil review sejumlah 25 artikel tersebut dituangkan di dalam sub bab hasil dan diskusi sehingga pertanyaan penelitian akan terjawab di sub bab kesimpulan. Pencarian literatur yang sesuai dengan kriteria inklusi, dibagi di dalam beberapa grup untuk mempermudah menjawab pertanyaan penelitian.

\section{Hasil}

Hasil literatur review didapatkan setelah melalui proses pencarian literatur dan seleksi, terdapat 25 artikel yang diulas (review). Literatur review dimulai dengan mencari epidemiologi rabies di dunia kemudian mengerucut hingga ke Indonesia. Rabies merupakan penyakit lama, yang ada sejak abad 18, namun hingga saat ini belum berhasil dieliminasi. Menurut data dari WHO, prevalensi rabies terdapat di seluruh dunia dan sebanyak $60 \%$ infeksi terjadi di Asia. ${ }^{2,8}$

Gambar 2 menunjukan peta penyebaran rabies di dunia selama kurun waktu tahun 20102014. Daerah yang berwarna biru menunjukkan daerah endemis kasus rabies. Terlihat bahwa rabies terdapat di beberapa bagian Amerika Selatan, Benua Afrika dan benua Asia, termasuk Indonesia.

Rabies adalah penyakit menular dari hewan ke manusia yang disebabkan oleh virus lyssa, famili Rhabdoviridae. Penularan utama rabies melalui Gigitan Hewan Pembawa Rabies (GHPR), terutama anjing. Virus akan menginfeksi sistem saraf tepi dan menuju ke otak setelah manusia tergigit oleh HPR. Pada saat virus menyerang otak, gejala klinis yang timbul di manusia adalah enchepalomyelitis

Pencarian dimulai pada 10-7-2019 hingga 12-7-2019 dengan memakai kata kunci Pelayanan Kesehatan, PEP, dan

Rabies center, menemukan 56 literatur yang memuat tentang kasus rabies di dunia



Gambar 1. Metode Literatur Review 




Gambar 2. Peta Penyebaran Kasus Rabies di Dunia²

dan hidrofobia, yang merupakan gejala khas rabies. Jika manusia yang tergigit oleh HPR sudah menunjukkan gejala klinis tersebut maka prognosa kasus menjadi infausta. World Health Organization (WHO) memperkirakan kematian manusia akibat rabies sebesar 55.000 orang di seluruh dunia setiap tahunnya, di mana sebanyak 99\% kematian tersebut terjadi di Afrika dan Asia. Di Indonesia, dilaporkan sebanyak 150-300 kasus rabies pada manusia setiap tahunnya. ${ }^{2,10}$

Langkah strategis pengendalian rabies terletak pada pemberian vaksinasi massal pada anjing dan pembatasan pergerakan anjing liar. Hal ini dilakukan di kota Memphis dan Shelby, Amerika Serikat tahun 1948 yang berhasil menurunkan kasus rabies di hewan dan manusia menjadi $0 \%$. Hal serupa terjadi di Bali, yang dapat menurunkan kasus rabies karena menerapkan vaksinasi rabies pada anjing. ${ }^{11}$

Sepanjang tahun 2010-2013, lebih dari 130 orang meninggal akibat rabies, hal itu terutama karena penderita GHPR tidak mendapatkan PEP, meskipun PEP telah diberikan terhadap lebih dari 130.000 orang penderita GHPR. ${ }^{12}$

Pencegahan rabies pada manusia ada dua tahap yaitu Pre-exposure prophylaxis (PreP), yaitu pemberian VAR pada individu yang berisiko tinggi sebelum terpapar oleh Hewan Penular Rabies dan Post-exposure prophylaxis (PEP), yaitu pencucian luka gigitan dengan air mengalir dan sabun selama 15 menit, kemudian diberikan injeksi VAR dan Serum Anti Rabies (SAR atau Rabies Immunoglobulin/ RIG). ${ }^{2,8}$

Infeksi rabies pada manusia merupakan masalah kesehatan masyarakat utama di dunia.
Sekitar 98\% kasus rabies di manusia terjadi di negara berkembang, hal ini karena banyaknya populasi anjing, yang sebagian besar anjing liar. Kasus gigitan rabies banyak terjadi di anak-anak. Diperkirakan kematian manusia akibat rabies di Asia dan Afrika masing-masing sebesar 30.000 dan 23.000. Biaya pemberian PEP di Asia dan Afrika diperkirakan US 583.5 juta. $^{2,13,14}$

Penyuntikan Pre exposure prophylaxis dapat diberikan ke peneliti rabies, pekerja laboratorium dan pekerja yang berisiko tinggi terkena yaitu dokter hewan dan tim serta pemelihara HPR yaitu anjing, kucing, monyet, dan kelelawar. Pemberian Pre exposure prophylaxis adalah suntikan vaksin rabies sebesar 1 dosis Human Diploid Cell Vaccine (HDCV) atau Purified Chick Embryo Vaccine (PCEC) yang diberikan melalui suntikan intra muskular di daerah deltoid. Suntikan VAR tersebut diberikan pada hari ke 0, 7, dan 21 atau 28. 2,15

Menurut WHO, Rabies adalah penyakit zoonosis yang terabaikan dan terjadi di negaranegera tropis. Rabies merupakan penyakit zoonosis yang memiliki tingkat kematian sangat tinggi. Pengendalian rabies dapat dilakukan dengan melihat dari status epidemiologi rabies sehingga biaya pengendalian dapat ditekan. Kasus rabies jarang terjadi di negara-negara industri seperti di Amerika Utara, Eropa, Selandia Baru, Malaysia, Arab dan Australia. Kasus rabies yang tinggi terdapat di negara-negara Asia dan Afrika, dan terjadi di masyarakat yang memiliki tingkat ekonomi rendah. ${ }^{14}$

Kejadian rabies banyak terjadi negara berkembang pada penduduk yang memiliki tingkat perekomonian rendah. Salah satu tindakan 
pencegahan yang dapat dilakukan terhadap pasien Lyssa adalah pemberian PEP yang terdapat di fasilitas pelayanan kesehatan primer di tiap-tiap daerah. Melihat dari meningkatnya kasus rabies pada manusia dan hewan yang saat ini berkurang menjadi 8 daerah bebas rabies yang semula adalah 9 provinsi, maka sangat perlu tindakan pencegahan yang intensif dan kolaboratif diantara sektor kesehatan manusia, kesehatan hewan dan satwa liar, karena untuk mengendalikan rabies dibutuhkan kerjasama lintas sektoral dalam konsep one health, mengingat WHO mencanangkan pada tahun 2030 dunia bebas dari rabies. Hal tersebut merupakan tantangan bagi Indonesia untuk mewujudkan bebas rabies tahun 2030 di 26 provinsi. ${ }^{14,16}$

Kesiapan fasilitas pelayanan kesehatan primer, dalam hal ini puskesmas dalam menghadapi tantangan rabies, sangat dibutuhkan terutama dalam hal promosi kesehatan rabies, yaitu tentang bahaya rabies dan bahaya gigitan rabies, juga dalam hal pemberian tindakan pencegahan pada penderita GHPR yaitu pemberian PEP.

Terkait dengan PEP, WHO menyarankan ada 3 kategori gigitan yang layak untuk mendapatkan PEP, dapat dilihat di Tabel 1. Berdasarkan Tabel 1, hanya kategori II dan III yang berhak untuk mendapatkan PEP. Kategori III juga berhak untuk mendapatkan PEP ditambah dengan suntikan SAR atau RIG. ${ }^{22}$

Peran fasilitas kesehatan sangat penting dalam mengendalikan kasus Lyssa, terkait mencegah angka kematian yang terus bertambah. Edukasi terhadap masyarakat sangat penting, dan hal ini termasuk di dalam promosi kesehatan yang menjadi tugas dan tanggung jawab puskesmas sebagai fasilitas pelayanan primer. Promosi kesehatan ini wajib dilakukan di 26 provinsi yang merupakan daerah endemis rabies. Hal ini dikarenakan virus rabies mudah mengalami inaktivasi dengan sabun atau deterjen, sehingga edukasi mengenai pencucian luka harus segera dilakukan paska mendapat gigitan dari HPR. Tindakan pencucian luka bertujuan untuk meminimalkan jumlah virus rabies yang berada di lokasi luka gigitan sehingga infeksi lebih lanjut dapat dicegah. Selain promosi kesehatan mengenai tindakan pencucian luka dengan segera, fasilitas kesehatan yang ditunjuk sebagai Rabies center wajib menyediakan VAR dalam jumlah cukup dan tersedia di dalam rantai dingin. Vaksin Anti Rabies tersebut dapat diberikan dalam bentuk PreP dan PEP tergantung dari status seseorang tersebut.

Fasilitas kesehatan yang terdapat di beberapa negara Asia juga memiliki peran penting untuk mengendalikan kasus Lyssa. Di dalam bab pembahasan dibahas mengenai peran fasilitas kesehatan di negara Bangladesh, Butan, Srilangka dan Kamboja.

\section{Pembahasan}

Gejala klinis rabies pada manusia adalah ; nyeri atau gatal di lokasi luka gigitan (dalam $80 \%$ kasus), demam, malaise (tidak enak badan), sakit kepala selama 2-4 hari, hidrofobia (takut akan air), tidak tahan pada suara gaduh, cahaya terang atau air, marah, mudah tersinggung dan depresi, hiperaktif, pada tahap akhir penderita mengalami kejangkejang di leher dan tenggorokan jika melihat air. Gejala klinis berlangsung selama $2-3$ hari, namun

\section{Tabel 1. Kategori Kontak dengan Hewan Suspek Rabies ${ }^{2,3,22}$}

\begin{tabular}{|c|c|c|}
\hline Kategori & Definisi & Pemberian PEP \\
\hline I & $\begin{array}{l}\text { Menyentuh atau memberi makan hewan, terkena jilatan hewan } \\
\text { pada kulit yang utuh }\end{array}$ & Tidak perlu \\
\hline II & $\begin{array}{l}\text { Terkena gigitan kecil, luka lecet akibat gigitan namun tidak } \\
\text { berdarah }\end{array}$ & $\begin{array}{l}\text { - Segera berikan PEP } \\
\text { - Cuci luka gigitan dengan air } \\
\text { mengalir dan sabun selama } 15 \text { menit }\end{array}$ \\
\hline III & $\begin{array}{l}\text { Kulit robek dan terkena saliva HPR, yaitu anjing, kucing, } \\
\text { termasuk kelelawar (tidak termasuk tikus), luka gigitan dalam }\end{array}$ & $\begin{array}{l}\text { - } \text { Pemberian PEP } \\
\text { - } \text { Pemberian SAR } \\
\text { - Terapi luka }\end{array}$ \\
\hline
\end{tabular}


dapat memanjang hingga 5-6 hari atau lebih jika pasien menerima dukungan perawatan intensif. ${ }^{6}$

Mayoritas kematian manusia akibat rabies di Asia disebabkan oleh gigitan anjing. Kasus rabies tertinggi terdapat di India dan menyumbang sebanyak $35 \%$ total kematian rabies di dunia. Berdasarkan hal ini, biaya PEP di Asia tertinggi sedunia, diperkirakan sebesar US\$ 1.5 juta per tahun. ${ }^{18}$

Kasus rabies pada manusia dapat dicegah melalui pencucian luka gigitan, pemberian PEP dan pemberian serum anti rabies (SAR atau RIG). Pemberian PEP dapat dilakukan paska manusia mendapat gigitan dari HPR yaitu anjing, kucing, kelelawar dan monyet dan gigitan terjadi di daerah enzootik rabies. Pemberian PEP tetap dapat dilakukan meskipun HPR telah memiliki riwayat vaksinasi rabies. Terdapat beberapa kasus Lyssa (rabies pada manusia) akibat gigitan monyet, dengan masa inkubasi selama 37,5 bulan. ${ }^{17,18}$

\section{Post Exposure Prophylaxis (PEP)}

Post Exposure Prophylaxis merupakan langkah untuk mencegah rabies pada manusia (Lyssa). Langkah yang sangat efektif untuk mengendalikan rabies adalah pemberian vaksinasi pada anjing, sebagai induk semang utama. Namun langkah ini sulit berjalan optimal karena banyak faktor, misalnya keengganan masyarakat pemilik anjing untuk memvaksinasi anjing peliharaan karena berkembang sugesti bahwa pemberian vaksin rabies akan membuat daya tahan tubuh anjing menjadi lemah. Faktor hambatan lainnya adalah tidak dapat menjamin anjing liar yang berkembang di jalanan telah divaksinasi rabies sebanyak $100 \% .{ }^{19-21}$

Pemberian PEP ke penderita GHPR melalui suntikan intramuskular dari 1 vial vaksin, sedangkan suntikan secara intradermal dapat diberikan kurang dari 0,5 vial. Pemberian PEP ini sangat efektif untuk mencegah kematian akibat gigitan rabies. ${ }^{22}$

Pengendalian rabies membutuhkan lintas sektoral, yaitu sektor kesehatan hewan, kesehatan manusia, lingkungan dan dukungan kebijakan pemerintahan daerah serta pusat. Peran sektor kesehatan manusia dalam menghadapi rabies adalah mempersiapkan fasilitas layanan kesehatan sebagai Rabies center.

Dasar hukum terbentuknya Rabies center adalah UU No 32 Tahun 2004 tentang Pemerintah Daerah, UU No 36 Tahun 2009 tentang kesehatan, UU No 18 Tahun 2009 tentang Peternakan dan Kesehatan Hewan, UU No 41 Tahun 2014 tentang Perubahan Atas UU No 18 Tahun 2009 tentang Peternakan dan Kesehatan Hewan, Perpres No 30 Tahun 2011 tentang Pengendalian Zoonosis, International Health Regulation tahun 2005, PP No 47 Tahun 2014 tentang Pengendalian dan Penanggulangan Penyakit Hewan, Permenkes No 1501 Tahun 2010 tentang Jenis-Jenis Penyakit Menular Tertentu yang Dapat Menimbulkan Wabah dan Upaya Penanggulangan dan Permenkes No 82 Tahun 2014 Tentang Pengendalian Penyakit Menular.

Rabies center adalah fasilitas pelayanan kesehatan (puskesmas atau rumah sakit) yang ditunjuk oleh Dinas Kesehatan Kabupaten/Kota untuk melaksanakan fungsi tatalaksana kasus GHPR dan promosi kesehatan terkait pengendalian rabies di wilayah kabupaten/kota tersebut dalam rangka menyediakan pelayanan kesehatan bagi masyarakat sekitar. Puskesmas yang ditunjuk sebagai Rabies center dapat memberikan pelayanan kasus GHPR yang berasal dari luar wilayah kerja Puskesmas karena tidak semua puskesmas ditunjuk sebagai Rabies center. Hal ini karena ada beberapa syarat yang harus dipenuhi untuk menjadi Rabies center yaitu : 1) Tersedia dokter atau paramedis yang terlatih atau tersosialisasi dalam penanganan rabies, 2) Tersedia fasilitas rantai dingin untuk tempat penyimpanan SAR dan atau VAR yang berfungsi baik, yaitu refrigerator bersuhu $2^{\circ} \mathrm{C}-8^{\circ} \mathrm{C}$, 3) Kesinambungan tersedianya VAR minimal 1 kuur (4 vial), 4) Tersedia sarana air mengalir untuk cuci luka GHPR, 5) tersedia media komunikasi, informasi dan edukasi (KIE) tentang pengendalian rabies, 6) lokasi puskesmas strategis dan mudah dijangkau oleh masyarakat, 7) memiliki Surat Keputusan penetapan dari Kepala Dinas Kesehatan Provinsi atau Kabupaten atau Kota.

Tugas dan tanggungjawab Rabies center adalah sebagai berikut : 1) memberikan pelayanan pertama berupa cuci luka GHPR dengan sabun dan air mengalir selama 15 menit terhadap semua penderita GHPR yang datang ke Rabies center, 2) melakukan anamnesa yang baik terhadap penderita GHPR untuk menentukan tata laksana kasus yang tepat, 
3) melakukan pencatatan dan pelaporan terhadap semua kasus GHPR, 4) melakukan pencatatan dan pelaporan terhadap stok logistik VAR dan SAR ke Dinas Kesehatan setempat, 5) melakukan koordinasi dengan sektor peternakan setiap ada penderita GHPR yang datang ke Rabies center, 6) memberikan penyuluhan sederhana ke masyarakat mengenai cara pencegahan penularan rabies, 7) melakukan rujukan atau konsultasi ke rumah sakit terhadap kasus, 8) melakukan pengamatan epidemiologis sederhana terhadap rabies.

\section{Penanggulangan rabies di empat negara asia}

Asia masih merupakan daerah endemis rabies, beberapa negara Asia telah melakukan serangkaian program pengendalian rabies untuk menurunkan kasus rabies dan Lyssa di negara masing-masing. Pada review ini, diulas empat negara yaitu Bangladesh, Butan, Srilangka dan Kamboja.

\section{Bangladesh}

Setiap tahun terjadi kematian manusia akibat GHPR sebanyak 2.000 kematian manusia dari 166.000 kasus gigitan, yang sebagian besar oleh gigitan anjing. Pengendalian rabies di Bangladesh menganut konsep One health. Konsep One health yaitu semua sektor dilibatkan untuk bersama-sama mengendalikan rabies, dan didukung oleh komitmen politik yang kuat dari para pejabat, adanya alokasi dana untuk melakukan pengendalian dan program vaksinasi HPR yang secara kontinyu dilakukan. ${ }^{23}$

Fasilitas layanan kesehatan primer yang bertanggungjawab memberikan PEP atau Rabies center terdapat di 66 kabupaten. Rabies center tersebut memberikan PEP ke penderita gigitan HPR sebanyak 500 orang setiap harinya. ${ }^{13,23}$ Pemberian PEP dan SAR diberikan secara gratis pada masyarakat yang terkena gigitan HPR. Masyarakat hanya membayar biaya spuit yang digunakan untuk menyuntikkan PEP sebesar US\$ 0.13. Jika stok PEP di Rabies center habis, penderita gigitan HPR dapat membeli PEP di apotik sebesar US\$ 8.25 untuk PEP atau VAR, dan sebesar US\$12.50 untuk SAR. Biaya pembelian VAR dapat ditanggung bersama-sama oleh beberapa penderita gigitan HPR karena 1 vial VAR dapat untuk beberapa dosis pemberian.

Pengadaan PEP dilakukan secara terpusat,

yaitu oleh Kementerian Kesehatan. Laporan penggunaan PEP dilakukan oleh Dinas Kesehatan setempat ke jenjang yang lebih tinggi hingga ke pusat rutin setiap bulan. Rantai dingin PEP juga dilakukan secara seksama. Vaksin VAR disimpan di Rabies center di dalam kulkas bersuhu $2-8^{\circ} \mathrm{C}$. Pasien paska pemberian PEP akan diberikan kartu catatan yang akan mengingatkan kapan harus kembali untuk dilakukan suntikan ulangan.

\section{Butan}

Pada tahun 2016, terdapat 7.900 kasus gigitan HPR dan 1 kasus kematian manusia akibat rabies. Penanggulangan rabies di Butan juga memakai konsep One health, yaitu strategi penanggulangan rabies di hewan dan manusia. Sistem pelayanan kesehatan di Butan terdiri dari 1 lembaga di pusat, yang membawahi 2 fasilitas kesehatan tingkat regional, di bawahnya terdapat 30 rumah sakit kabupaten yang membawahi 210 unit kesehatan dasar.

Bahan-bahan PEP dan SAR disediakan di unit kesehatan dasar ini dan gratis bagi masyarakat yang terkena gigitan HPR. Pemberian PEP hanya dilakukan di sektor pemerintahan, tidak di sektor swasta. Ketersediaan SAR terdapat dalam jumlah terbatas karena memiliki harga yang mahal. Hal ini juga yang menyebabkan tidak semua penderita gigitan HPR kategori III mendapatkan SAR. Kondisi seperti ini juga terjadi di Indonesia, yaitu penderita gigitan HPR kategori III sebagian besar dapat diberikan PEP, namun tidak selalu dibarengi dengan pemberian SAR. ${ }^{7,20,24}$

Sama seperti di Bangladesh, VAR diperoleh dari Direktorat Pengadaan Alat dan Bahan Medis di Kementerian Kesehatan Butan dari UNICEF. Vaksin VAR kemudian didistribusikan ke rumah sakit kabupaten melalui rantai dingin. Permintaan VAR dilakukan oleh unit kesehatan dasar ke rumah sakit kabupaten. Fasilitas kesehatan yang meyediakan PEP memiliki buku stok opname mengenai PEP tersebut yang berisi tentang data stok PEP dan nomer register, serta tanggal expired dan pembuatan VAR. Kartu vaksin juga diberikan ke penderita gigitan HPR paska diberikan PEP. Jika terdapat reaksi samping paska pemberian PEP juga dapat dilaporkan ke fasilitas kesehatan setempat. . $^{1822}$

\section{Srilangka}

Srilangka telah memiliki program nasional pengendalian rabies sejak tahun 1975 paska 
ditemukan kasus kematian manusia akibat rabies di tahun 1971. Kasus gigitan HPR sebanyak 150.000 setiap tahun. Selama tahun 2000an, kasus kematian manusia akibat rabies menurun menjadi 20 orang pada tahun 2016, yang semula sebanyak 50-60 kasus kematian. Keberhasilan penurunan kasus ini disebabkan oleh program pengendalian nasional tersebut yang terdiri dari upaya maksimal dalam penyuntikan rabies pada HPR, dan penyediaan PEP secara gratis. Bahan-bahan PEP disediakan di 204 unit rabies yang berlokasi di tiap-tiap rumah sakit. Rumah sakit tipe besar memiliki VAR dan SAR, namun rumah sakit tipe kecil hanya menyimpan VAR. Unit rabies yang terdapat di tiap-tiap rumah sakit memiliki sedikitnya satu tempat tidur dan satu komputer untuk pelaporan secara elektronik.

Tenaga medis yang terdapat di unit rabies juga telah diberikan pelatihan mengenai PEP. Berbeda dengan di Butan, PEP disediakan juga di sektor swasta namun dalam jumlah yang sedikit dan harga yang mahal. Sama seperti halnya di Butan dan Bangladesh, pengadaan PEP dilakukan oleh Kementerian kesehatan. Penyaluran PEP ke daerah dilakukan memakai rantai dingin. Unit rabies memiliki PEP yang tersimpan di dalam kulkas tersendiri, terpisah dengan bahan biologi lainnya. Meskipun stok PEP ada setiap tahun, namun selalu dilebihkan sedikit untuk mengantisipasi adanya lonjakan kasus gigitan HPR. Kelebihan stok ini disimpan hanya di fasilitas kesehatan pusat, dan hanya didistribuskan ke daerah jika ada laporan kasus. Tiap-tiap unit rabies sudah memiliki fasilitas elektronik untuk mencatat data demografi pasien gigitan, status gigitan dan data VAR mengenai tanggal pembuatan dan kadaluarsa. Tiap-tiap unit juga memiliki data stok opname VAR. Jika terdapat pasien gigitan HPR yang berisiko tinggi, dilakukan pemantauan status pasien per telepon atau kunjungan langsung ke pasien. ${ }^{22,25}$ Seperti dua negara lainnya, jika terjadi efek samping akibat pemberian PEP akan dilaporkan secara sistematis.

\section{Kamboja}

Kamboja memiliki kasus gigitan HPR sebanyak 700.000, dan kematian manusia akibat gigitan HPR sebanyak 800 orang setiap tahun. Tidak seperti tiga negara tersebut diatas, Kamboja belum memiliki program pengendalian rabies secara nasional. Pemberian vaksinasi rabies ke anjing pun tidak dilakukan secara rutin. Terdapat tiga institusi pemerintahan yang menyediakan PEP, yaitu Angkor Hospital for Children (AHC) di Siem Reap, the Institut Pasteur du Cambodge (IPC) rabies vaccination center dan National Institutes of Public Health (NIPH) clinic di Phnom Penh.

Penderita gigitan HPR dapat menerima VAR dan SAR dengan biaya subsidi di IPC sebesar masing-masing US\$ 12 untuk VAR dan US\$ 37 untuk SAR. Ketersediaan SAR hanya terbatas di dua institusi yaitu AHC dan IPC dengan pemberian diprioritaskan pada penderita gigitan HPR kategori 3, umur penderita dan status anjing. The Institut Pasteur du Cambodge (IPC) setiap tahunnya menerima pasien untuk suntikan VAR sebanyak 22.000 orang, sedangkan AHC menerima pasien PEP sebanyak 3.000 orang. Vaksin VAR terdapat di NIPH namun penderita gigitan HPR harus membayar sebesar US\$ $8-15$ per dosis. Vaksin VAR diberikan secara suntikan intra dermal di AHC dan IPC, dan secara intra muskular hanya di NIPH. Vaksin VAR juga terdapat di seluruh klinik swasta. Klinik NIPH dan IPC memakai database elektronik untuk memantau status stok VAR, dan juga data mengenai pasien PEP yaitu data demografi, merk vaksin, rute penyuntikan, status rabies anjing, kategori gigitan, tanggal penyuntikan PEP. Ketiga institusi tersebut memberikan kartu terhadap pasien yang telah mendapatkan PEP. Ketiga institusi tersebut melaporkan ketersediaan PEP setiap bulan ke Kementerian Kesehatan Kamboja.

Melihat pengendalian rabies yang telah dilakukan di empat negara tersebut, terlihat bahwa fasilitas pelayanan kesehatan memiliki fungsi penting untuk mengendalikan kasus rabies pada manusia. Fungsi tersebut antara lain penyediaan VAR dan SAR untuk penderita GHPR. Namun PEP tidak tersedia di semua fasilitas pelayanan kesehatan. Bahan PEP hanya tersedia di fasilitas layanan kesehatan yang ditunjuk oleh Pemerintah Pusat, dan terintegrasi dengan tiap-tiap unit rabies. Hal ini karena biaya 1 vial VAR mahal, dan VAR disuntikkan sebanyak minimal lebih dari satu kali. Ketersediaan SAR juga terbatas di empat negara. Pemberian SAR diprioritaskan ke penderita gigitan berusia anak-anak, penderita gigitan yang parah dan terletak di daerah kepala, serta status hewan yang menggigit. Jika hewan yang menggigit 
selama observasi menunjukkan gejala klinis rabies atau mati dan hasil pemeriksaan laboratorium menunjukkan positif rabies, maka penderita GHPR wajib mendapatkan SAR. ${ }^{3,8}$

Sistem distribusi PEP di empat negara tersebut bersifat independen, tidak bersama-sama dengan vaksin lainnya. Di Bangladesh, PEP terlokasi di tingkat kabupaten, setelah didistribusikan dari tingkat pusat. Di Srilangka, PEP didistribusikan dari tingkat pusat ke fasilitas kesehatan di bawah. Di Kamboja, PEP terdapat di tiga institusi yang diberi kepercayaan oleh pemerintah untuk memberikan PEP ke masyarakat korban gigitan HPR. Di Butan, EPI bertanggungjawab terhadap distribusi, ketersediaan dan rantai dingin PEP.

Merujuk dari pengalaman keempat negara tersebut, peran fasilitas pelayanan kesehatan yang ditunjuk sebagai Rabies center, sangat penting untuk mengendalikan kasus rabies karena mayoritas kasus rabies di dunia, juga di Indonesia terdapat di daerah pedesaan yang merupakan daerah kerja fasilitas pelayanan kesehatan primer. ${ }^{1,2}$ Kesamaan yang ada di Indonesia adalah adanya rabies center. Rabies center yang dapat berupa puskesmas atau rumah sakit, selain memberikan PEP pada masyarakat yang tergigit oleh HPR, juga melakukan promosi kesehatan ke masyarakat mengenai rabies dan apa yang dilakukan jika tergigit oleh hewan rabies. Hal ini disebabkan karena sebagian besar masyarakat tidak mengetahui apa yang harus dilakukan jika tergigit oleh HPR. Masyarakat belum mengetahui bahaya jika tergigit oleh HPR, sehingga seringkali penderita gigitan HPR datang ke faslitas pelayanan kesehatan sudah dalam kondisi parah, yaitu sudah terlihat gejala klinis rabies. ${ }^{12,24}$

Perbedaan rabies center yang ada di Indonesia dengan di ketiga negara tersebut adalah pada jumlah. Jumlah rabies center di ketiga negara tersebut tidak sebanyak di Indonesia yaitu diharapkan ada di tiap-tiap kabupaten/kota pada 26 provinsi endemis rabies.

Kasus rabies banyak terjadi di negara berkembang, hal ini disebabkan populasi anjing terutama anjing liar banyak dan belum diketahui ekologi anjing. Disamping itu, tingkat pengetahuan masyarakat mengenai gigitan anjing masih rendah. Masyarakat masih belum mengetahui bahaya gigitan anjing atau HPR lainnya seperti kucing, monyet dan kelelawar. Masyarakat juga belum mengetahui upaya-upaya pencegahan terhadap rabies seperti cuci luka gigitan segera dengan air mengalir dan sabun, dan pemberian PEP yaitu VAR dan SAR yang terdapat di rabies center. Pengendalian rabies ini harus dilakukan secara optimal, mengingat tingkat kematian manusia akibat rabies di Asia sebesar 31.000 orang atau terdapat satu kematian akibat rabies setiap 20 menit, dan sebagian besar kematian terjadi pada anak-anak. Kasus rabies banyak terjadi di daerah pedesaan, di mana rasio manusia dan anjing sebesar 14:3, dibandingkan dengan daerah perkotaan, yang berasio 7:4. Hal itu berarti masyarakat yang tinggal di pedesaan berisiko tinggi untuk tergigit oleh anjing rabies karena jumlah manusia lebih banyak dibandingkan dengan jumlah anjing. ${ }^{2-4,7}$

Peran puskesmas dalam upaya promosi kesehatan untuk pengendalian rabies sangat penting mengingat manyarakat belum banyak mengetahui tentang bahaya gigitan dan pentingnya pemberian PEP, termasuk dimana saja puskesmas yang dapat memberikan PEP. Pembelajaran yang didapat dari kasus outbreak rabies di Bali bahwa sebagian besar masyarakat tidak mengetahui dimana harus mendapatkan PEP setelah terkena gigitan anjing. Hal ini membutuhkan peningkatan pengetahuan pemilik anjing, sehingga dapat diberikan penyuluhan mengenai rabies kepada mereka.

Hal-hal yang harus diketahui dan dilakukan oleh rabies center adalah berikut ini ${ }^{6}$ :

1. Tindakan yang dilakukan terhadap luka gigitan

Luka harus segera dicuci dan dibasuh dengan sabun dan air mengalir selama 10-15 menit. Jika tidak ada sabun, basuh dengan air mengalir saja. Langkah ini merupakan perawatan pertolongan pertama yang paling efektif terhadap rabies. Luka harus dibersihkan secara menyeluruh di fasilitas layanan kesehatan dengan menggunakan alkohol $70 \%$ atau povidone-iodine. Lakukan penilaian terhadap status vaksinasi misalnya apakah vaksinasi diphtheria, pertussis, tetanus (DPT) atau tetanus toxoid sudah pernah diberikan sebelumnya. Jika diperlukan, suntikan tetanus toxoid harus diberikan. Harus diberikan resep antibiotik untuk mencegah kemungkinan infeksi bakteri. 
2. Kontra indikasi pada luka gigitan hewan

Tenaga medis di puskesmas harus mengetahui tindakan yang tidak boleh dilakukan terhadap luka gigitan, yaitu: 1) menutupi luka dengan kain pembalut atau perban, 2) menjahit luka yang menyebabkan inokulasi atau masuknya virus rabies lebih dalam. Namun jika harus dijahit, maka menjahit luka harus dilakukan setelah infiltrasi luka dengan Rabies immunoglobulin (RIG). Rabies immunoglobulin yang berasal dari manusia (HRIG) harganya mahal dan hanya tersedia dalam jumlah terbatas. Rabies immunoglobulin yang berasal dari kuda (ERIG) tersedia di banyak negara dan lebih murah daripada HRIG. Jahitan luka harus longgar dan tidak mengganggu darah keluar dengan bebas dan mengering.

3. Penyimpanan VAR yang baik dan benar agar dapat menjaga keamanan dan potensi vaksin sebelum diberikan

Vaksin Anti Rabies berbentuk kering beku (freeze-dried), sehingga memiliki umur simpan dan kestabilan yang lebih lama. Vial vaksin harus dijaga agar tetap dingin dan disimpan di kulkas pada suhu $2^{\circ} \mathrm{C}-8^{\circ} \mathrm{C}$. Vaksin rekonstitusi harus digunakan sesegera mungkin karena ini adalah vaksin dosis tunggal. Jika digunakan untuk vaksinasi rabies intradermal, vaksin rekonstitusi harus digunakan dalam jangka waktu 6 jam dan disimpan pada suhu $2^{\circ} \mathrm{C}-8^{\circ} \mathrm{C}$.

4. Pemberian VAR dan immunoglobulin ke ibu hamil atau menyusui

Vaksin Anti Rabies dapat diberikan ke ibu hamil atau ibu menyusui. Vaksin tersebut tidak memberikan efek pada pertumbuhan janin selama masa kehamilan atau anak yang menyusu selama masa penyusuan. Virus rabies diketahui tidak dapat menembus barrier plasenta ibu, sehingga bayi yang dilahirkan melalui bedah caesar dari ibu penderita rabies berstatus sehat.

5. Jenis VAR yang digunakan di negara endemik rabies di kawasan Asia Tenggara

Vaksin anti rabies yang digunakan dapat dikategorikan berdasarkan asalnya, seperti berikut: 1) berasal dari kultur jaringan, yaitu bentuk human diploid cell vaccine (HDCV), purified Vero cell rabies vaccine (PVRV), dan 2) telur berembrio, yaitu purified chick-embryo cell vaccine (PCECV) dan purified duck embryo vaccine (PDEV).

\section{Kesimpulan}

Peran fasilitas pelayanan kesehatan primer dalam mengendalikan rabies pada manusia sangat penting, yaitu; 1) melakukan tatalaksana pertama kali terhadap korban GHPR melalui pencucian luka gigitan melalui air mengalir, 2) menyediakan VAR dalam jumlah cukup yang dalam hal ini memerlukan pencatatan yang baik dan dilaporkan ke Dinas Kesehatan setempat, 3) promosi kesehatan yang dilakukan oleh tenaga kesehatan terlatih tehadap masyarakat sekitar karena tingkat pengetahuan sebagian besar masyarakat terhadap rabies masih rendah, sehingga membutuhkan promosi kesehatan yang optimal.

\section{Saran}

Rabies dapat dicegah dengan perilaku hidup yang tanggap terhadap fungsi pelayanan kesehatan sehingga peran fasilitas pelayanan kesehatan yang ditunjuk sebagai Rabies center dapat mengoptimalkan promosi kesehatan melalui pemberian leaflet, edukasi rabies di sekolah-sekolah dasar, pemasangan spanduk rabies dan pemutaran video rabies di puskesmas atau rumah sakit di ruang tunggu pasien sehingga pasien dapat melihat dan mengetahui mengenai rabies dan pencegahannya.

\section{Ucapan Terima Kasih}

Ucapan terima kasih ditujukan kepada yang telah membantu dalam penulisan review artikel ini yaitu Kasubdit Zoonoosis beserta staf di Subdit Zoonosis Direktorat Pengendalian dan Pencegahan Penyakit (P2P) Kementerian kesehatan RI.

\section{Daftar Rujukan}

1. Dodet B, Goswami A, Gunasekera A, Guzman F De, Jamali S, Montalban C, et al. Rabies awareness in eight Asian countries. Vaccine. 2008;26:6344-8. DOI : 10.1016/j. vaccine. 2008.09.003

2. Gongal G, Wright AE. Human Rabies in the WHO Southeast Asia Region : Forward Steps for Elimination. Advances in Preventive Medicine. 2011;2011:1-5. DOI : doi:10.4061/2011/383870.

3. WHO Expert Consultation on Rabies, third report. Geneva: World Health Organization; 2018 (WHO Technical Report Series, No. 1012). Licence: CC BY-NC-SA 3.0 IGO 
4. Digna M, Widyastuti W, Bardosh KL, Basri C, Basuno E, Jatikusumah A, et al. On dogs , people, and a rabies epidemic : results from a sociocultural study in Bali, Indonesia. Infect Dis Poverty [Internet]. 2015;1-18. Available from: http://dx.doi.org/10.1186/s40249-0150061-1

5. Rabies Center. Buku Saku. 2017. Direktorat Pencegahan dan Pengendalian Penyakit. Kementerian Kesehatan Republik Indonesia. Jakarta.

6. FAQs Pertanyaan yang Sering Diajukan tentang Rabies. World Health Organization, Regional Office for South East Asia. 2013;1-59. Jenewa

7. Townsend SE, Sumantra IP, Bagus GN, Brum E, Cleaveland S, Crafter S, et al. Designing Programs for Eliminating Canine Rabies from Islands : Bali , Indonesia as a Case Study. PLOS. Neglected Tropical Diseases.2013;7(8): e2372. doi:10.1371/journal.pntd.0002372

8. Fahrion Anna S., Alexei Mikhailov, Bernadette Abela-Ridder, Jolene Giacinti, Joanne Harries. Human rabies transmitted by dogs: current status of global data. Weekly Epidemiological Record. World Health Organization. 2016;91(2):1-20

9. Sitepu FY, Depari E, Sianturi C. Evaluasi program pencegahan dan pengendalian rabies dalam rangka menuju Sumatera Utara bebas rabies. J.Health.Epidemiol. 2018;4(2):42-48.

10. Wera E, Velthuis AGJ, Geong M, Hogeveen H. Costs of Rabies Control: An Economic Calculation Method Applied to Flores Island. PLOS ONE.2013;8(12):e83654. doi:10.1371/ journal.pone. 0083654

11. Putra Agung A, Hampson K, Girardi J, Hiby E, et al. Response to a Rabies Epidemic, Bali, Indonesia, 2008-2011. Emerging Infectious Diseases.2013;19(4):2008-11.

12. Wera E, Mourits MCM, Hogeveen H. Uptake of Rabies Control Measures by Dog Owners in Flores Island,Indonesia. PLOS Neglected Tropical Diseases. 2015;1-23. e83654. doi:10.1371/journal.pone. 0083654

13. Hossain M, Bulbul T, Ahmed K, Ahmed Z, Salimuzzaman M, Shahidul M, et al. Five-year ( January 2004 - December 2008 ) surveillance on animal bite and rabies vaccine utilization in the Infectious Disease Hospital, Dhaka ,
Bangladesh. Vaccine.2011;29(5):1036-40. Available from: http://dx.doi.org/10.1016/j. vaccine.2010.11.052

14. Lavan RP, Macg AI, Sutton DJ, Tunceli K. Rationale and support for a One Health program for canine vaccination as the most cost-effective means of controlling zoonotic rabies in endemic settings. Vaccine. 2017;35(13):1668-74. Available from: http://dx.doi.org/10.1016/j. vaccine.2017.02.014

15. Mohammad Khalid Mohammad and Pratibha Gupta. A study of human rabies cases admitted in infectious disease hospital. Int J Community Med Public Health. 2018;5(11):4795-4798.

16. Budayanti N.N.S., Penanggulangan Rabies Berbasis Konsep One Health Sebagai Program Pemerintah Daerah Bersama. Kajian Ilmiah. Universitas Udayana.2016;1-20

17. Gautret P, Angelo KM, Asgeirsson H, Lalloo DG, Shaw M, Schwartz E, et al. Rabies postexposure prophylaxis started during or after travel : A GeoSentinel analysis. PLOS Neglected Tropical Diseases.2018;12(11): e0006951. https://doi.org/ 10.1371/journal.pntd.0006951

18. Dhand NK, Ward MP. Human rabies post exposure prophylaxis in Bhutan , 2005 2008: Trends and risk factors. Vaccine. 2011;29(24):4094-101.

19. Technology F, Card A. crossm First Complete Genomic Sequence of a Rabies Virus from the Republic of Tajikistan Obtained Directly from a Flinders Technology Associates Card. Genome Announc: 5:e0515-17. https://doi.org/10.1128/ genomeA.00515-17.

20. Arief RA. Corrigendum: Determinants of Vaccination Coverage and Consequences for Rabies Control in Bali, Indonesia. Front. Vet. Sci.2017;3:123. doi: 10.3389/fvets.2016.0012

21. Utami Sri Utami, Bambang Sumiarto. Tingkat dan Faktor Risiko Kekebalan Protektif terhadap Rabies pada Anjing di Kota Makassar. Jurnal Veteriner. 2012;13(1):77-85.

22. Lanka S, Li AJ, Sreenivasan N, Ruman U, Tahmina S, Penjor K, et al. Descriptive assessment of rabies post-exposure prophylaxis procurement, distribution, monitoring, and reporting in four Asian. Vaccine. 2018;20178. Available from: https://doi.org/10.1016/j. 
vaccine.2018.10.011

23. Ahmed M.H., T. Bulbul, S.Hossain, A. Rahman.M. N. U. Biswass and A. Nishizono. Human rabies in rural Bangladesh. Epidemiol. Infect. 2019;(6):1964-71.

24. Gunesekera A, Janakan N, Gongal G, Abelaridder B. Sri Lanka takes action towards a target of zero rabies death by 2020. WHO South- East
Asia J Public Health. 2016; 5(2): 113-116.

25. Mustiana A, Toribio J, Abdurrahman M, Suadnya IW. Owned and Unowned Dog Population Estimation, Dog Management and Dog Bites to Inform Rabies Prevention and Response on Lombok Island, Indonesia. PLOS ONE.2015;10(5): e0124092. doi:10.1371/ journal.pone. 0124092 